\title{
クロレラ原藻末中のクロロフィラーゼ活性と光過敏症発現
}

(昭和 55 年 7 月 4 日受理)

$\begin{array}{ll}\text { 関 洋 治*1 } & \text { 冨金原 } \text { 孝*1 }^{* 1} \\ \text { 松浦栄 }{ }^{* 2} & \text { 山田幸二 }\end{array}$

\section{Relation between Photosensitization of Rats by Chlorella Powder and Chlorophyllase Activity in the Powder}

\author{
Yoji Seki*1, Takashi Fukimbara*1, Eiichi MaStura*2 \\ and Koji YAMADA*3
}
( ${ }^{* 1}$ Rokko Bio-science Research Laboratory Co., Ltd.: 730-5, Tsurugasone, Yashio-shi, Saitama;
${ }^{* 2}$ Kitazato University: 1, Asamizodai, Sagamihara-shi Kanagawa; ${ }^{* 3}$ Koriyama Women's College: 3-25-2, Kaisei, Koriyama-shi, Fukushima)

Rats were fed Chlorella powder, and the appearance of photosensitization was investigated in relation to chlorophyllase activity in the Chlorella powder. The sensitivities of different experimental animals to photosensitization were also examined. The differences of chlorophyllase productivity among three strains of Chlorella were studied. The following results were obtained.

1. The appearance of photosensitization in rats seemed to be correlated with chlorophyllase activity in Chlorella powder, and particularly with total contents of formed chlorophyllide and initial pheophorbide.

2. It was observed that the rat was more sensitivity to the photosensitization than the mouse.

3. It was found that the chlorophyllase activities in three strains of Chlorella were rather different from each other under the same conditions of culture.

(Received July 4, 1980)

Key words: クロレラ原藻末 Chlorella powder; 光過敏症 photosensitization; クロロフィラーゼ 活性 chlorophyllase activity; フェオホーバイド pheophorbide; クロロフィライド chlorophyllide

\section{まえがき}

クロレラの光過敏症については，ほとんど知られてい ないが，昭和 52 年に，クロレラ錠剤摂取による皮膚炎事

*1（株）鹿光生物科学研究所：埼玉県八潮市鶴每䁌根 $730-5$

*2 北里大学: 神奈川県相模原市麻溝台 1

*3 郡山女予大学：福島県郡山市開成 3-25-2

*4 真野 覚, 松浦栄一, 関 洋治, 冨金原 孝: 炤和 53 年日本農芸化学大会講演要旨集, p. 394 (1978).
件が起きだ．

その原因について，田村ら 2) は，原因物質はフェオホ ーバイド a とそのェステル類であると推定し，また成 形工程にアルコールを用いると，クロロフィラーゼが賦 活化され，フェオホーバイド a が多量に生成されるこ とを指摘し，これにより皮㲊炎を発生したのではないか と推論した。

真野ら*4は, 同じく光過敏症の誘因を追究し, 成型加 工法は別にして, クロレラ原藻末中に既にその誘因が存 
在し, 原藻末中のクロロフィラーゼ活性が比較的強い場 合は，これを摂取すると，消化過程を通じて光感作物質 が生成され，原藻末に既存する光感作物質にこれが加算 されて同症を発生することを動物試験により確かめ, 原 藻末中のクロロフィラーゼ活性を熱処理により減少させ ることにより，同症の発生を防ぐことの可能なことを示 唆した。

また，天野ら は)はクロレラ製品および原藻末（東海緑 藻工業 (株) 製）から抽出した色素を分析し, クロロフィ ルに分解物で光力学的作用を有する既知物質中にフェオ ホーバイド a の存在を確認し，またクロロフィル分解 物の生成にはクロロフィラーゼが関与し，この酵素活性 が原藻末のみならず製品中にも残存していることを認 め, この酵素作用は温度, 湿度により賦活化されること を指摘し，クロロフィル分解物の量的規制だけでは不十 分で, クロロフィラーゼの残存活性について十分に注意 を払らことの必要性を示唆した。

以上の知見を総合すると，クロレラ製品を製造するに 当たって, 安全性のある加工法を選ぶ必要のあることは 言うまでもないが，その前提として，まず使用する原料 の安全性の確認が必要であると思われる.

本報告は, クロレラの光過敏症発生防止の一対策とし て，原藻末中のクロロフィラーゼ活性に着目し，動物試 験により光過敏症発現との関連性を観察すると同時に， 光過敏症検定に対する実験動物の感受性の差異ならびに クロレラ藻種によるクロロフィラーゼ活性の差異につい て検討し，2，3 の知見を得たので報告する.

\section{実験方法}

\section{1. クロレラ原藻末中のクロロフィラーゼ活性と光過 敏症発現の関連性について}

\section{1-1）供試試料}

台湾および国内産のクロレラ原藻末 11 種を試料とし た.

\section{1-2）クロロフィル総量の測定}

\section{クロロフィル総量の測定は A. O. A. C.4)によった.}

\section{1-3） クロロフィル誘導体量の測定}

クロロフィル誘導体量の測定は，柳沢ら*5の方法によ った.すなわち，クロレラ原藻末に水を加えて十分に磨 砕した後これに $80 \%$ 濃度になるよらにメタノールを 加えて放置後, 遠心操作により上澄液を分離した. 残椬 は90〜95\%メタノールで同一操作で 4 回繰り返し抽出 した. 次いで総抽出液に等量のエーテルを加兄て水洗操 作で色素をェーテル層に移行させ, エーテル層を無水硫 酸ナトリウムで脱水した後一定容量とし, 光電分光光度 計 ((株) 島津製作所, UV-200型)を用い, 660 と 642.5 $\mathrm{nm}$ の吸光度を測定して, これを粗クロロフィル量とし た. 次いで, 同一エーテル溶液一定量をとり, エーテル

*5 柳沢昊永, 遠藤 寛, 代田 稔: 昭 36 年日本農芸 化学大会講演要旨集, p. 81 (1961).
を蒸発後 $70 \%$ アセトン溶液で色素を溶解し, 等量のnヘキサンを加えて十分にかくはんした後, 遠心分離して 上層の全へキサン層を取り出し, ヘキサンを蒸発させて 色素をエーテルに再溶解し, 前記同様に吸光度を測定 し，これを純クロロフィル量として，また粗クロロフィ ル量と純クロロフィル量の差をクロロフィル誘導体量と して表した。 なお，この測定法によるクロロフィル誘導 体は, ペーパークロマトグラフィーでは, 主にフェオホ 一バイド a, b, クロロフィライド a, b, カロチノイドな ぞが検出される.

\section{1-4）フェオホーバイト総量の測定5)}

試料 $50 \mathrm{mg}$ をとり，85\% アセトン $20 \mathrm{ml}$ を加えて, 30分間放置した後, これを石英砂とともに磨砕してク口 ロフィル類を抽出し，この抽出液に同量のエチルエーテ ルを加えて，これを分液漏斗に移し， $5 \%$ 硫酸ナトリウ ムを加えて振り混ぜ, 2 層に分離させた後, 上部のエー テル層をとり, 蒸留水で洗う. 次に，このエーテル層を 濃度の異なる塩酸溶液 (1，8 および 15\%) で分画抽出を 行い, $15 \%$ 塩酸区分を分取し, 同量のクロロホルムを加 えて，激しく振とうして放置する．このクロロホルム層 をとり, 同量の蒸留水で数回水洗した後, 減圧下で, ク ロロホルムを蒸発させ, これをェチルエーテルに溶解さ せて, 無水硫酸ナトリウムを加えて脱水し, これを一定 容積とした。

このエーテル溶液の吸収スペクトルを光電分光光度計 を用いて, 700 から $630 \mathrm{~nm}$ までスキャニングさせて, 最大吸収波長 $667 \mathrm{~nm}$ の点から $680 \mathrm{~nm}$ と $650 \mathrm{~nm}$ を 結ぶ直線上に，垂線をおろし，この直線の長さを測り， 天野ら ${ }^{3)}$ の方法で調製したフェオホーバイド a を用い て，その標準曲線をつくり，試料中の $15 \%$ 塩酸区分中 のクロロフィル分解物の濃度をフェオホーバイド a の の量として求めた.

\section{1-5） クロロフィラーゼ活性の測定}

クロロフィラーゼ活性の測定については, 種々の方法 が報告されている(6) 10). これらの方法は主として, 生の 状態の試料が用いられている. 本報告では, 試料は熱処 理による乾燥工程を経たものであるので，上記の方法が そのまま用いられるかについて検討したところ，クロロ フィラーゼの抽出が十分に行われないことがわかりここ れらを採用することは避けた。 そこで, Holden の方 法11)に準じて, 試料中に存在しているクロロフィルを基 質として，同試料中にあるクロロフィラーゼで分解し て，クロロフィラーゼ活性を求めた。

すなわち，試料 $0.5 \mathrm{~g}$ をとり，70\% アセトン $50 \mathrm{ml}$ 中に眯濁させ, 密せんして室温, 暗所に16時間放置し, 試料中のクロロフィラーゼを同試料中のクロロフィルに 反応させた。この懸濁液を $70 \%$ アセトン溶液と残椬に ろ別し，残椬を $99 \%$ アセトンで洗浄し，この溶液を上 記の $70 \%$ アセトンに合し，この溶液にエチルェーテル 
を加えて色素類をエーテルに転溶させ，エーテル層を十 分に水洗してアセトンを除いた後, 無水硫酸ナトリウム を加えて脱水後一定容積とした。この一部をとり，光電 分光光度計を用いて, $660 \mathrm{~nm}$ および $642.5 \mathrm{~nm}$ におけ る吸光度を測定しこれよりクロロフィル量 (I)を求 めた ${ }^{12), 13)}$.

次に, 上記エーテル残渣液を適度に減圧濃縮したのち 分液漏斗に移し， $0.05 \%$ の水酸化ナトリウム溶液を加 学て ${ }^{14)}$ ，るやかに振とうし，しばらく放置すると 2 層 に分離する．この下層（クロロフィライド層）を捨て， 上部のエーテル層を分取し，これに無水硫酸ナトリウム を加えて脱水後一定容積とし，クロロフィライドを除い たクロロフィル量 (II)を, 前記と同様に求めた.

クロロフィライドの生成量は, (I)-(II) の值で示し, クロロフィラーゼ活性は次式により算出した.

クロロフィラーゼ活性 ( $\mathrm{mg} \%)$

$$
=\frac{\text { クロロフィライド生成量 }(\mathrm{mg})}{\text { 試料 }(\mathrm{g})} \times 100
$$

\section{1-6) 動 物 試 験}

体重 $100 \mathrm{~g}$ 前後のドンリュウ型雄ラットを用いて, 基 本飼料（カゼイン $20 \%$, 大豆油 $5 \%$, 混合塩 $4 \%$, ビタ ミン末 $1 \%$ および小麦でん粉を含む）に，試料の各ク口 レラ原藻末 $10 \%$ を添加した飼料を 1 日量 $20 \mathrm{~g}$ として 2 日間投与し，その間恒温恒湿の暗室で飼育し，3 日間 に照度 20,000 lux の可視光線を 7 時間照射した。なお， 光照射装置は ${ }^{5) \cdot 15)}$ 光源としてタングステンランプ $(200$ W） 8 個を用い，金網製のケージにラットを入れて，紫 外線および熱線を除くために, 光源ランプから約 $5 \mathrm{~cm}$ 下にガラス製水槽を設けて，照射中絶えず $2 \mathrm{~cm}$ の深さ で泠水を循環させ, ケージ内の温度を $25 \pm 3^{\circ}$ 以下に保 った. 試験には 1 群 5 匹を用い, 光過敏症の発生は, 供 試動物の耳介の障害（紅斑）および死亡を以て判定し た.なお, 後記の Table 2 および 3 に示されている分 数は, 分母は供試動物数, 分子は紅斑発生あるいは死亡 動物数を示した.

\section{2. 光過敏症に対する実験動物の感受性について}

光過敏症の検定用動物としては, 主としてラットが用 いられているが16) 21)，時にはマウスも用いられている ので2),20)，両動物を用いて光過敏症に対する感受性につ いて試験した。なお, 試験方法は次の 2 つの方法に分け て行った.

\section{2-1） 短期間投与による動物試験}

東海緑藻工業製のクロレラ原藻末（A）を用いて，こ れを 1-6）に示した基本飼料に $10 \%$ 添加して供試飼料 Aとした.

ラットに対しては，1-6) に示した方法で試験を行い， マウスに対しては体重 $30 \mathrm{~g}$ 前後の ICR 系マウス 5 匹 を 1 群として, 上記飼料を 1 日量 $5 \mathrm{~g}$ として 2 日間投 与し，その間恒温恒湿の暗室で飼育し， 3 日目に照度
20,000 lux の可視光線を 7 時間照射し, その間の光過 敏症の発生について観察した。

\section{2-2）長期間連続投与による動物試験}

供試飼料は，前記の供試飼料 $\mathrm{A}$ のほか，もら一種の東 海緑藻工業 (株)製のクロレラ原藻末（B）を用いて，こ れを前記同様に $10 \%$ 添加して供試飼料 B とした。なお， （B）については，2-1）の方法により, 光過敏症の判定 済（紅斑 $5 / 5$, 死亡 3/5）のもので, 長期間連続投与試 験は，マウスについてのみ行った（ラットについては, 前記の判定結果を代用することにした).

マウスについては, 体重 $30 \mathrm{~g}$ 前後の ICR 系マウス 5 匹を 1 群とし， 5 日間自由給与させて， 6 日間に照度 20,000 lux の可視光線を 5 時間照射して，その影響を 観察したのち, 再び暗室にもどして 7 日間観察を続け た. 両投与法とも光照射装置は，1-6）に示したものを 用いた。

3. 藻種によるクロロフィラーゼ生成の差異について 3-1) 分析方法

Chlorella A-28, Chlorella pyrenoidosa 77105 および Chlorella No. 5 を用いた.

酢酸を炭素源とする混合培養 (mixotropic) 方式で, 坂ロフラスコで振とう培養したものを種藻とし，これを ジャ一培養に移して増殖培養を行った.

培地組成：Table 1 に示す培地を用いた。

培養条件：振とう培養は, $500 \mathrm{ml}$ 容坂ロフラスコに Table 1 の培地を $100 \mathrm{ml}$ 入れて, 殺菌冷却後, それぞ れ供試藻種を無菌的に接種して振幅 $6.5 \mathrm{~cm}$, 振とら数 $150 \mathrm{rpm}$, 照度 1400 lux, 温度 $30 \sim 35^{\circ}$ で 7 日間培養し たものを，それぞれ種藻とした。

ジャ一培養は， $2 \mathrm{~L}$ 容ガラス製ジャ一を用い, 上記同 様の培地を $1 \mathrm{~L}$ 入れて, 殺菌冷却後, 無菌的に上記の種 藻をそれぞれ接種し，照度 3,000～5,000 lux, 温度 $28^{\circ}$, 通気量 $1 \mathrm{vvm}(1 \mathrm{~L} / \mathrm{min})$ ，かくはん $700 \mathrm{rpm}$ で, 7 日 間増殖培養を行った。

藻体容積：ヘマトクリット管を用いて，3000 rpm, 20 分間遠心分離した後の同管の目盛 $(\mathrm{ml} / \mathrm{L})$ で示した。

藻体乾燥重量：1050 で乾燥させたときの重量 $(\mathrm{g} / \mathrm{L})$ で示した。なお，藻体の洗浄は，蒸留水で 2 回行った。

Table 1. Medium Composition in Chlorella Cultivation

$\begin{array}{lc}\mathrm{CH}_{3} \mathrm{COONa} & 5 \mathrm{~g} / \mathrm{L} \\ \mathrm{CO}\left(\mathrm{NH}_{2}\right)_{2} & 2 \mathrm{~g} / \mathrm{L} \\ \mathrm{MgSO}_{4} \cdot 7 \mathrm{H}_{2} \mathrm{O} & 1 \mathrm{~g} / \mathrm{L} \\ \mathrm{KH}_{2} \mathrm{PO}_{4} & 1 \mathrm{~g} / \mathrm{L} \\ \mathrm{CaCl}_{2} & 0.01 \mathrm{~g} / \mathrm{L} \\ \mathrm{FeSO}_{4} \cdot 7 \mathrm{H}_{2} \mathrm{O} & 0.005 \mathrm{~g} / \mathrm{L} \\ \mathrm{A}_{5} \text { stock soln. } & 1 \mathrm{ml} / \mathrm{L} \\ \mathrm{pH} & 6.0\end{array}$

Shaking culture: $30 \sim 35^{\circ} \mathrm{C}, 1,400 \mathrm{lux}, 150 \mathrm{rpm}$ Jar culture: $28^{\circ} \mathrm{C}, 3,000 \sim 5,000$ lux, $1 \mathrm{vvm}$ 
クロロフィラーゼ活性の測定：培養液 $20 \mathrm{ml}$ を 24 時 間ごとにとり, 洗浄, 遠心分離して得られるぺースト状 の生藻体について，1-5)に示す分析法によりクロロフィ ラーゼ活性を測定した.

クロロフィル含量：上記同様の方法で得られたペース ト状の生藻体について，1-2)に示す分析法によりクロロ フィル含量 $(\%)$ を測定した.

\section{結果および考察}

1. クロレラ原藻末中のクロロフィラーゼ活性と光過 敏症発現の関連性について

台湾および国内産11種のクロレラ原藻末中のクロロフ ィル総量, クロロフィル誘導体量, フェオホーバイド総 量およびクロロフィラーゼ活性の測定結果ならびに各原
藻末に対する光過敏症発現の判定結果は, Table 2 に示 す通りであった。

Table 2 にみられるよらに，原藻末中に既存するフェ オホーバイド量については，この值が低いものでも光過 敏症は発現している。 またクロロフィル誘導体量につい ては,この值が低いものでも同症は発現し，また逆に比 較的に高いものでも同症は発現しないので，既存のフェ オホーバイドおよびクロロフィル誘導体量だけでは, 光 過敏症発現の関連性を求めることはできない。しかしク ロロフィラーゼ活性值については，この值が低い場合 は，同症を発現しておらず，高い場合に同症を発現して いるので，光過敏症の発現には，クロロフィラーゼ活性 の大小が関連性をもっていることがうかがわれ，光過敏

Table 2. Relation between Chlorophyllase Activity of Chlorella Powder and Photosensitization in rats

\begin{tabular}{|c|c|c|c|c|c|c|}
\hline \multirow{2}{*}{ Sample } & \multirow{2}{*}{$\begin{array}{c}\text { Chlorophyll } \\
(\%)\end{array}$} & \multirow{2}{*}{$\begin{array}{c}\text { Chlorophyllase } \\
\text { activity } \\
(\mathrm{mg} \%)\end{array}$} & \multirow{2}{*}{$\begin{array}{l}\text { Pheophorbide } \\
(\mathrm{mg} \%)\end{array}$} & \multirow{2}{*}{$\begin{array}{l}\text { Chlorophyll } \\
\text { derivatives } \\
(\mathrm{mg} \%)\end{array}$} & \multicolumn{2}{|c|}{ Photosensitivity } \\
\hline & & & & & Erythema & Death \\
\hline 1 & 1. 27 & 108.0 & 73.7 & 170.0 & $0 / 5$ & $0 / 5$ \\
\hline 2 & 2. 78 & 117.1 & 22.6 & 181.7 & $0 / 5$ & $0 / 5$ \\
\hline 3 & 3. 41 & 257.3 & 93.6 & 309.1 & $0 / 5$ & $0 / 5$ \\
\hline 4 & 2.09 & 185.2 & 41.0 & 131.0 & - & - \\
\hline 5 & 1.74 & 201.7 & 45.1 & 66.3 & - & - \\
\hline 6 & 2.11 & 997.2 & 786.2 & 134.2 & $5 / 5$ & $5 / 5$ \\
\hline 7 & 2.47 & 287.8 & 38.4 & 21.0 & $5 / 5$ & $4 / 5$ \\
\hline 8 & 2.16 & 337.9 & 24.7 & 539.7 & $5 / 5$ & $5 / 5$ \\
\hline 9 & 3.34 & 561.7 & 50.7 & 300.6 & $5 / 5$ & $4 / 5$ \\
\hline 10 & 1.43 & 547.5 & 82.7 & 89.1 & $2 / 5$ & $2 / 5$ \\
\hline 11 & 1.20 & 979.7 & 443.3 & 73.7 & $5 / 5$ & $5 / 5$ \\
\hline
\end{tabular}

Chlorophyllase activity: Chlorophyllide formed $(\mathrm{mg}) /$ Sample $(\mathrm{g}) \times 100$

Chlorophyll derivatives: Crude chlorophylls (ether soln)-Pure chlorophylls ( $r$-hexane layer)

Photosensitivity: No. of rats with lesions/Total No. of rats

Table 3. Difference of Sensitivity between Rat and Mouse in Photosensitization

\begin{tabular}{|c|c|c|c|c|c|}
\hline \multirow{2}{*}{\multicolumn{2}{|c|}{ Diets }} & \multirow{2}{*}{$\begin{array}{l}\text { Dose period } \\
\text { (days) }\end{array}$} & \multirow{2}{*}{ Species } & \multicolumn{2}{|c|}{ Photosensitivity } \\
\hline & & & & Erythema & Death \\
\hline \multirow[t]{2}{*}{ Exp. 1} & A & 2 & Rat & $2 / 5$ & $3 / 5$ \\
\hline & A & 2 & Mouse & $0 / 5$ & $0 / 5$ \\
\hline \multirow[t]{4}{*}{ Exp. 2} & A & 5 & Mouse & $0 / 5$ & $0 / 5$ \\
\hline & $A^{*}$ & 2 & Rat & $2 / 5$ & $3 / 5$ \\
\hline & $\mathrm{B}$ & 5 & Mouse & $5 / 5$ & $5 / 5$ \\
\hline & $\mathrm{B}^{*}$ & 2 & Rat & $5 / 5$ & $3 / 5$ \\
\hline
\end{tabular}

Exp. 1: Dose period for two days

Exp. 2: Dose period for five days

A: Basal diet $+10 \%$ Chlorella powder (A)

B: Basal diet $+10 \%$ Chlorella powder (B)

Photosensitivity: No. of rats with lesions/Total No. of rats

* Reference data 
症の発現の予知については, クロロフィラーゼにより生 成されるフェオホーバイド量を知ることが肝要であると 示唆された。

クロレラの光過敏症の発現の主な原因物質はフェオホ ーバイド a であり，これには原藻体中に既存するフェ オホーバイド a と, 生体内でクロロフィラーゼの作用 および消化過程により生成されるフェオホーバイド a が，同症の発現に関与する*4. したがってクロレラ錠剂 の安全性管理のためには, 両者の值を測定し，その兼ね 合い（既存フェオホーバイド+生成フェオホーバイド） をみることが大切なことになる．

\section{2. 光過敏症に対する実験動物の感受性について}

同種類のクロレラ原藻末を用いて，ラットおよびマウ スの光過敏症の発現について，その感受性を比較検討し たところ, Table 3 に示すとおりの結果が得られた.

Table 3 にみられるように，短期間投与試験 (Exp. 1 においては, ラットでは光過敏症の発現が明らかにみら れるが，マウスでは，同症の発現がまったくみられなか った. 長期間連続投与試験（Exp. 2) においては，ラッ トに対しては，短時間投与試験と全く同様の結果が得ら れると想定されるので, 前記のように, この試験は省略 して, 短期間投与試験結果 (A: 紅斑 $2 / 5$, 死亡 $3 / 5, B$ :
紅斑 $5 / 5$, 死亡 $3 / 5)$ で代用させた。

ラットに対しては, 供試飼料 A, B 共に, 光過敏症を 発現するが，マウスに対しては，A では光過敏症の発現 はみられなかったが, B では同症の発現がみられた。す なわち, 両試験においてラットで光過敏症を発生するも のが，マウスでは同症を発生しない事例が得られ，同症 の動物感受性に対して, 両者に幾分の差異があるように 観察された。なお，細部について検討する必要はあるが， クロレラの光過敏症検定動物としては, マウスよりラット を用いる方が適切な判定が得られるように推察された。

3. 藻種によるクロロフィラーゼ生成の差異について 同一条件で培養された，3藻種の各増殖培養における 藻体容積, 藻体乾燥重量, クロロフィラーゼ活性および クロロフィル量を測定したところ, Table 4 に示す通り の結果が得られた。

各藻種の増殖状態を藻体容積および乾燥重量からみる と，培養後 144〜168 時間経過すると，おおむね成長は 定常状態に入り, 各藻種のクロロフィラーゼ活性值は, 対数期を過ぎ定常状態に入るころ (96〜120 時間)に最高 值に達し，それ以後は減少の傾向を示し，またこの活性 值は藻種間で相当の差異が認められたが，これは培養条 件など一定にして培差を行っているので，各藻種の遺伝

Table 4. Time Course of Jar Culture by Three Strains of Chlorella

\begin{tabular}{ll|rrrrrrr}
\multicolumn{2}{c}{ Chlorella pyrenoidosa } & \multirow{2}{*}{77105} & \multicolumn{7}{c}{ Cultivation time (hr) } \\
\cline { 3 - 9 } & & 24 & 48 & 72 & 96 & 120 & 144 & 168 \\
\hline Packed cell volume & $(\mathrm{ml} / \mathrm{L})$ & - & - & - & 5.6 & 6.0 & 6.4 & 6.7 \\
Dry weight & $(\mathrm{g} / \mathrm{L})$ & - & - & - & 1.38 & 1.66 & 1.74 & 1.68 \\
Chlorophyll & $(\%)$ & - & - & - & 3.01 & 2.91 & 2.95 & 3.36 \\
Chlorophyllase activity* & $(\mathrm{mg} \%)$ & - & - & - & 956 & 927 & 717 & 722
\end{tabular}

\begin{tabular}{|c|c|c|c|c|c|c|c|c|}
\hline \multirow{2}{*}{ Chlorella A-28 } & & \multicolumn{7}{|c|}{ Cultivation time (hr) } \\
\hline & & 24 & 48 & 72 & 96 & 120 & 144 & 168 \\
\hline Packed cell volume & $(\mathrm{ml} / \mathrm{L})$ & 1.9 & 6.0 & 7.6 & 8.5 & 8.5 & 9.4 & 9.6 \\
\hline Dry weight & $(\mathrm{g} / \mathrm{L})$ & 0.52 & 1.64 & 1. 78 & 1.98 & 1.98 & 2.24 & 2.34 \\
\hline Chlorophyll & $(\%)$ & - & 1.52 & 2.26 & 2.85 & 2.85 & 2. 68 & 2. 42 \\
\hline Chlorophyllase activity* & $(\mathrm{mg} \%)$ & - & 1312 & 2095 & 2595 & 2595 & 2304 & 2026 \\
\hline
\end{tabular}

\begin{tabular}{|c|c|c|c|c|c|c|c|c|}
\hline \multirow{2}{*}{ Chlorella No. 5} & & \multicolumn{7}{|c|}{ Cultivation time (hr) } \\
\hline & & 24 & 48 & 72 & 96 & 120 & 144 & 168 \\
\hline Packed cell volume & $(\mathrm{ml} / \mathrm{L})$ & 0.8 & 4. 0 & 6.4 & 7.2 & 7.6 & 8.2 & 8.8 \\
\hline Dry weight & $(\mathrm{g} / \mathrm{L})$ & 0.1 & 0.77 & 1.26 & 1. 48 & 1. 48 & 1.96 & 2. 72 \\
\hline Chlorophyll & $(\%)$ & - & 2. 66 & 2.37 & 3.29 & 3.54 & 3.78 & 4. 08 \\
\hline Chlorophyllase activity* & $(\mathrm{mg} \%)$ & - & 547 & 544 & 610 & 599 & 409 & 527 \\
\hline
\end{tabular}

* Chlorophyllide formed $(\mathrm{mg}) /$ Sample $(\mathrm{g}) \times 100$ 
的性質の相違から生じているように思われ，藻種の選択 により，適正なクロロフィラーセ活性值の生藻体が得ら れる可能性が示された。

なお，生藻体におけるクロロフィラーゼ活性值は，ク ロレラ原藻末に比べてはるかに高い值であるが,これは, クロレラが回収され乾燥原藻末になるまでに，人為的な 物理的化学的変化を受けるために，クロロフィラーゼが 失活し，原藻末では，活性が弱くなっていることによる (例えば，スプレイ乾燥など)。

\section{要 約}

1.クロレラ原藻末に打ける光過敏症発現とクロロフ ィラーゼ活性の間には，相関的関係が認められ，かつ同 症の発現には, 既存フェオホーバイド量とクロロフィラ 一ゼによる生成クロロフィライド量が関与寸ることが認 められた。

2. 光過敏症検定用動物について，ラットとマウスを 用い，同症の感受性について検討したところ，マウスよ りラットの方が同症の感受性が敏感であるように観察さ れた。

3. クロレラの藻種を用いて，一定培養条件下で，ク ロロフィラーゼの生成の差異について検討したところ, 藻種間では同酵素の生成量に相当の差異のあることを認 め, 光過敏症発生防止の対策として藻種の選択も一つの 方法になることが示された。

おわりに，本研究の発表の許可を頂いた（株）鹿光生 物科学研究所社長鹿野光雄氏に深謝致します。

本報告の大要は, 日本食品衛生学会第36回学術講演会 (昭和53年12月，静岡）で発表した。

\section{文献}

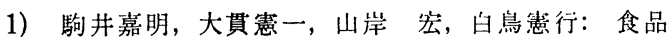
衛生研究, 28, 747 752 (1978).

2) 田村行弘, 西垣 進, 真水俊夫, 嶋村保洋, 直井 家壽太：同上，28，753７59 (1978)

3）天野立爾，池 慶予，内山 充：同上, 28, 739 745 (1978)

4) Offiic. Method of Analysis of Assoc. Offic.
Anal. Chem., 12 Edition, 3, 107 (1975).

5) Hashimoto, Y., Tsutsumi, J.: Bull. Japan Soc. Sci. Fisheries, 27, 859 866 (1961).

6) West, C. A., Mackinney, G.: J. Biol. Chem., 133, 551 558 (1940).

7) Gage, R.S., Aronff, S.: Plant Physiol., 31, 477 478 (1956)

8) Ardao, C., Vennesland, R.: ibid., 35, 368 371 (1960).

9) Böger, P.: Phytochem., 4, 435 443 (1965).

10) Chiba, Y., Idemori, M., Satoh, Y., Matsushita, K., Sasa, T.: Plant \& Cell Physiol., 8, 623 635 (1967).

11) Holden, M.: Biochem. J., 78, 359 364 (1967).

12) Comar, C. L., Zscheile, F. P.: Plant Physiol., 17, 198 209 (1942).

13) Holt, A. S., Jacobs, E. E.: Amer. J. Botany, 41, 710 717 (1954).

14）林 孝三: “生物学実験講座”, 第 6 巻上, 植物色 素実験法, p. 11 (1966), 中山書店.

15）山田幸二, 中村延生蔵：栄養と食䊓， 25，466～ 471 (1972).

16) Hashimoto, Y., Naito, K., Tsutsumi, J.: Bull. Japan Soc. Sci. Fisheries, 26, 1216 1221 (1960).

17) Hove, E. L., Lohrey, E., Urs, M. K., Allison, R. M.: Br. J. Nutr., 31, 147 $\sim 157$ (1974).

18) Lohrey, E., Tapper, B., Hove, E. L.: ibid., 31, 159 166 (1974).

19) Tapper, B., Lohrey, E., Hove, E. L., Allison, R. M.: J. Sci. Fd. Agric., 26, 277 284 (1975).

20）磯部明彦，木村修一：栄養と食䊅, 29, 221 224 (1976).

21）松浦栄一, 青木喜代子, 平野隆司, 山田幸二, 河 原裕憲：同上，30，307３11 (1977) 